1 Detection of Circulating Tumor-specific DNA Methylation Markers in the Blood of

2 Patients with Pituitary Tumors.

3 Michael Wells ${ }^{1,2}$, Karam P. Asmaro ${ }^{1,2}$, Thais S. Sabedot ${ }^{1,2}$, Tathiane M. Malta ${ }^{1,2}$,

4 Maritza S. Mosella ${ }^{1,2}$, Kevin Nelson ${ }^{1}$, James Snyder ${ }^{1,2}$, Ana deCarvalho ${ }^{1}$, Abir

5 Mukherjee ${ }^{3}$, Dhananjay Chitale ${ }^{3}$, Adam Robin ${ }^{1}$, Mark Rosenblum ${ }^{1}$, Thomas

6 Mikkelsen ${ }^{1}$, Laila M. Poisson ${ }^{4}$, Ian Y. Lee ${ }^{1}$, Tobias Walbert ${ }^{1}$, Arti Bhan ${ }^{6}$, Steven

7 Kalkanis ${ }^{1}$, Jack Rock ${ }^{1}$, Houtan Noushmehr ${ }^{1,2}$, Ana Valeria Castro ${ }^{1,2^{*}}$

$8{ }^{1}$ Department of Neurosurgery, Hermelin Brain Tumor Center, Henry Ford Health

9 System, Detroit, MI, USA

10 2Department of Neurosurgery, Omics Laboratory, Henry Ford Health System, Detroit,

$11 \mathrm{MI}, \mathrm{USA}$

$12{ }^{3}$ Department of Pathology, Henry Ford Health System, Detroit, MI, USA

$13 \quad{ }^{4}$ Department of Biostatistics, Henry Ford Health System, Detroit, MI, USA

$14{ }^{5}$ Department of Radiology, Henry Ford Health System, Detroit, MI, USA

$15{ }^{6}$ Department of Endocrinology, Henry Ford Health System, Detroit, MI, USA

\title{
$16{ }^{*}$ Corresponding author
}

17 Ana Valeria B. Castro, MD, PhD

18 Department of Neurosurgery

19 Hermelin Brain Tumor Center; Henry Ford Health System

202799 West Grand Blvd, E\&R 3096

21 Detroit, MI, 48202

22 acastro1@hfhs.org 
medRxiv preprint doi: https://doi.org/10.1101/2020.05.29.20116202; this version posted May 30, 2020. The copyright holder for this preprint (which was not certified by peer review) is the author/funder, who has granted medRxiv a license to display the preprint in perpetuity.

All rights reserved. No reuse allowed without permission.

\section{Abstract}

25 Genome-wide DNA methylation aberrations are pervasive and associated with

26 clinicopathological features across pituitary tumors (PT) subtypes. The feasibility to detect

27 CpG methylation abnormalities in circulating cell-free DNA (cfDNA) has been reported in

28 central nervous system tumors other than PT. Here, we aimed to profile and identify

29 methylome-based signatures in the serum of patients harboring PT $(n=13)$. Our analysis

30 indicated that serum cfDNA methylome from patients with PT are distinct from the

31 counterparts in patients with other tumors (gliomas, meningiomas, colorectal carcinomas,

$32 \mathrm{n}=134)$ and nontumor conditions $(n=4)$. Furthermore, the serum methylome patterns

33 across PT was associated with functional status and adenohypophyseal cell lineage PT

34 subtypes, recapitulating epigenetic features reported in PT-tissue. A machine learning

35 algorithm using serum PT-specific signatures generated a score that distinguished PT

36 from non-PT conditions with $100 \%$ accuracy in our validation set. These preliminary

37 results underpin the potential clinical application of a liquid biopsy-based DNA methylation

38 profiling as a noninvasive approach to identify clinically relevant epigenetic markers that

39 can be used in the management of PT.

41 Word count:

42 Title: 15

43 Abstract: 154

44 Main Text: 2,934

45 Methods: 1,272

46 References: 53 
medRxiv preprint doi: https://doi.org/10.1101/2020.05.29.20116202; this version posted May 30, 2020. The copyright holder for this preprint (which was not certified by peer review) is the author/funder, who has granted medRxiv a license to display the preprint in perpetuity.

\section{Introduction}

Liquid biopsy (LB) is a method used to detect molecular elements (e.g., DNA, RNA,

51 (cfDNA), specifically the tumor DNA fraction (ctDNA), is thought to originate from cellular

52 death (apoptosis and necrosis) or secretion from live cells, especially from proliferative

53 tissues or tumors ${ }^{1-5}$. Blood-based LB has emerged as a reliable and a minimally invasive

54 approach to identify clinically relevant molecular biomarkers from several tumor origins,

55 including from central nervous system (CNS) neoplasms ${ }^{5-8}$.

56 In contrast to CNS tumors that are shielded by the blood-brain barrier, the pituitary

57 gland presents an anatomical structure that facilitates the spillage of tumor cellular

58 material into the bloodstream, i.e. a fenestrated pituitary portal system and/or an access

59 to the cavernous system. This structural advantage creates an opportunity to profile

60 tumor-specific molecular features of material released from these tumors potentially

61 suitable for clinicopathological application ${ }^{9,10}$. Indeed, the feasibility to detect and

62 sequence somatic gene variants in ctDNA has recently been reported in PT ${ }^{1}$; however,

63 the detection sensitivity of this approach was low in these tumors ${ }^{1}$. The paucity of genetic

64 alterations in the pathogenesis of PT such as recurrent somatic mutations may have

65 contributed to these results ${ }^{11-15}$. In contrast, genome-wide methylation abnormalities

66 detected in the tissue are knowingly pervasive across PT subtypes ${ }^{13,16-23}$. Additionally,

67 DNA methylome patterns are tissue- and tumor-specific providing an opportunity to 68 predict the tissue of origin of the tumor through DNA methylation profiling 5,20,24,25. In fact,

69 many studies showed that specific methylome patterns detected in the tissue 70 distinguished PT from other CNS tumors and defined discrete methylation subtypes 
medRxiv preprint doi: https://doi.org/10.1101/2020.05.29.20116202; this version posted May 30, 2020. The copyright holder for this preprint (which was not certified by peer review) is the author/funder, who has granted medRxiv a license to display the preprint in perpetuity.

All rights reserved. No reuse allowed without permission.

71 among different CNS tumors 20,26,27. Additionally, methylation markers presented

72 diagnostic, prognostic and predictive applications in CNS tumors $20,26,27$. The feasibility of

73 detecting these tissue- or tumor-specific methylation signatures using a liquid biopsy

74 approach is an emerging field that has not been reported in PT to date.

75 In this study, we profiled the serum cfDNA methylome derived from patients with

76 PT or other tumors and nontumor conditions. We identify unique methylation signatures

77 in the serum associated with clinicopathological features specific to PT. This proof-of-

78 concept study paves the way for the potential clinical application of a liquid biopsy as a

79 noninvasive approach to identify and assess relevant epigenetic markers that may be

80 useful in the management of patients with PT.

\section{Results}

82 Characterization of pituitary cell-free DNA methylome

83 cfDNA quantification

84 Total extracted serum cfDNA quantity, normalized to the genomic size $(\mathrm{ng} / \mathrm{ml}$, see

85 Methods), were not significantly different from controls (mean $\pm S D, 59.3 \pm 134.2$ vs $5 \pm 5.0$

$86 \mathrm{ng} / \mathrm{ml}$, respectively; $\mathrm{p}=.14$ ) or in relation to functional or invasion status in PT

87 (Supplemental Figure 1A).

88 Deconvolution

89 The deconvolution of the serum cfDNA methylome showed that patients harboring PT

90 had higher proportion of bulk pituitary gland signatures compared to the control serum

91 and other CNS conditions ( $3 \%$ higher, $p=.05$ )(Supplemental Figure 1B; Supplemental

92 Table 2).

93 Methylome analysis 
medRxiv preprint doi: https://doi.org/10.1101/2020.05.29.20116202; this version posted May 30, 2020. The copyright holder for this preprint (which was not certified by peer review) is the author/funder, who has granted medRxiv a license to display the preprint in perpetuity.

All rights reserved. No reuse allowed without permission.

94 The genome-wide mean methylation landscape of the serum cfDNA from patients with

95 PT and non-PT conditions (gliomas, meningiomas, colorectal carcinomas and nontumor

96 conditions) showed that PT segregated into a hypomethylated and a hypermethylated

97 cluster; the latter, shared similar CpG methylation degree with the serum methylome from

98 patients with glioma, meningioma, colorectal cancer and nontumor controls (Figure 1A

99 and 1B).

100

Conducting a supervised analysis between PT and non-PT serum specimens and

101 selecting probes that shared similarities with the matching PT tissue (Supplemental

102 Figure 1D, left), we identified 46 differentially methylated probes (DMP), namely Pituitary

103 Tumors-specific Epigenetic-Liquid Biopsy (PeLB) probes, that significantly distinguished

104 both groups (Figure 1B) and distinguished two subgroups across PT (hyper and 105 hypomethylated) (Figure 1C),

106 The two methylation clusters were associated with distinct clinicopathological 107 status, i.e. the hypermethylated cluster was predominantly composed of nonfunctioning,

108 mainly encompassed by SF1 lineage and null cell tumors and the hypomethylated with 109 functioning PT mostly comprised of Pit1-lineage tumors (Figure 1 C). As an exception, 110 one lactotroph adenoma/Pit1-lineage segregated with nonfunctioning PT, despite being 111 clinically classified as functioning, and a functioning Tpit1-lineage tumor clustered with 112 nonfunctioning tumors. These results recapitulate the findings in their matching tissue

113 (Supplemental Figure 1E).

114 cfDNA methylome from patients with PT pituitary-specific epigenetic signatures 115 distinct from other pathological conditions. 
medRxiv preprint doi: https://doi.org/10.1101/2020.05.29.20116202; this version posted May 30, 2020. The copyright holder for this preprint (which was not certified by peer review) is the author/funder, who has granted medRxiv a license to display the preprint in perpetuity.

All rights reserved. No reuse allowed without permission.

116 Overlapped with tumor tissues, PeLB probes clustered with PT tissue and significantly 117 separated PT from other CNS tumor-tissue, confirming PeLB-specificity to PT in an

118 independent cohort (Figure 1D). Taking this feature into account, we developed and 119 cross-validated a score derived from a machine learning (ML) model (repeated 5000 120 times), namely the PeLB score, to predict whether a serum specimen originates from a 121 patient with PT or a non-PT condition (Figures 1E-F). Pituitary-derived serum methylome samples carried the highest values of PeLB score (71-99\%), whereas the serum of non-

123 PT tumors carried the lowest values (0-45\%) (Figure F). The evaluation of the model in 124 the validation sample set showed that the model performed with an accuracy of $100 \%$, 125 taking into account a 50\% PeLB cutoff.

We also defined serum-based methylation signatures $(n=70)$ accounting for the 127 functional/lineage status of PT (nonfunctioning vs functioning PT) $(p<.01$, differential 128 mean methylation $>.2$, FDR <.26), we named functioning-PeLB (Func-PeLB)(Figures 2A, Supplemental Figure 1D, right). Harnessing the methylome from matching tissue 130 and publicly available data reporting on the functional status of PT, we observed that a 131 subset of the Func-PeLB probes (overlapped with the 450K platform, used to profile the 132 tissue-methylome of those samples) ( $\mathrm{n}=22$ probes) (Supplemental Figure 1D, right), 133 also discriminated the two functional groups at the tissue and respective serum levels 134 (Figure 2B-D)

135 The CpG probes that distinguished the methylation clusters either in tissue $136(n=5000)$ or serum (6000) were most frequently located in open sea regions $(67 \%$ and $13761 \%$, respectively) and gene bodies (61 and 55\%, respectively) (Figure 1B,

\section{Supplemental Table 2).}


medRxiv preprint doi: https://doi.org/10.1101/2020.05.29.20116202; this version posted May 30, 2020. The copyright holder for this preprint (which was not certified by peer review) is the author/funder, who has granted medRxiv a license to display the preprint in perpetuity.

All rights reserved. No reuse allowed without permission.

\section{Discussion}

Methylome-derived signatures define molecular subtypes that are useful for the

141 diagnosis and prognostication across many tumors 13,16-18,20,21,26-29. Additionally,

142 genome-wide DNA methylation patterns are cell-specific either in healthy or tumor

143 specimens $5,18,20,24,25,30-32$. The ability to detect methylation signatures and tumor-specific

144 abnormalities by the profiling of circulating cell-free DNA (cfDNA) in biofluids (liquid 145 biopsy), such as blood, has been useful for the early detection and surveillance of 146 malignant neoplasms ${ }^{5,33-35}$. In relation to CNS tumors, our group has recently reported 147 on the feasibility to identify methylation-based markers in serum-derived cfDNA for the 148 diagnosis and prognostication of gliomas and meningiomas ${ }^{36}$. Herein, we show that, 149 similar to malignant and other CNS tumors, PT releases tumor-related information in the 150 blood that allows the identification of clinically relevant methylation signatures specific to 151 patients with PT, namely PeLB probes (Figure 1A-B; Supplemental Figure 1D). 152 Capitalizing on the specificity of these probes, we used a machine learning approach to 153 generate the PeLB score (Figure 1D-E) to predict the presence of a pituitary tumor using 154 liquid biopsy. We showed that PeLB score performed with a 100\% accuracy to predict 155 that serum was derived from patients with PT in our validation cohort (Figure 1F). These 156 results remain to be confirmed in an independent cohort of PT-derived, currently 157 unavailable.

In addition, distinct serum DNA methylation landscape, specifically PeLB probes, 159 defined two methylation groups that recapitulated the clinicopathological findings 160 displayed in their matching tissue as reported in other studies ${ }^{13,16-18,20,21}$ (Figure 1C-D,

161 Supplemental Figure 1E). These serum-derived clusters showed that the 
medRxiv preprint doi: https://doi.org/10.1101/2020.05.29.20116202; this version posted May 30, 2020. The copyright holder for this preprint (which was not certified by peer review) is the author/funder, who has granted medRxiv a license to display the preprint in perpetuity.

162 hypermethylated group was enriched by nonfunctioning PT mainly originated from SF1 and Tpit cell lineages and the hypomethylated set mainly composed of functioning PT mostly originated from Pit-1 cell lineages (Figure 1C, Supplemental Figure 1D). We narrowed down to a subset of PeLB probes (Func-PeLB) that preserved the distinction between both clusters in tumor-tissue specimens as well (Figure 2C, Supplemental

167 Figure 1D). Altogether, these results suggest that PT releases DNA methylation markers in the serum that reflect clinicopathological features such as functional status and adenohypophyseal lineage of these tumors. Confirmation of these findings in a larger and more comprehensive cohort lay the groundwork to the application of PeLB probes as an

171 objective approach to classify PT according to cell-lineage as recommended by the 2017 $172 \mathrm{WHO}^{37}$.

174 serum-methylation markers specific to the invasion status of PT. Corroborating the 175 findings reported in the tissue, we found slight serum differences between invasive and 176 noninvasive groups (data not shown) ${ }^{13,16,17,21}$. However, the association of tissue- or 177 serum-derived methylation groups with the criteria that better predict PT with higher risk 178 to progress or recur remains to be elucidated ${ }^{13,18,38-43}$.

179 The application of PeLB score is not intended to replace the standard approaches 180 to diagnose and classify PT which, in most of the cases, is satisfactorily performed by 181 clinical features, hormonal assessment in the blood/urine and on the imaging of the 182 pituitary gland ${ }^{44}$. However, these results provide evidence that serum cfDNA constitutes 183 a reliable source of clinically relevant tumor-specific epigenetic signatures in PT as 184 observed in other CNS tumors ${ }^{36}$. Potentially, the specificity of PeLB probes could be 
medRxiv preprint doi: https://doi.org/10.1101/2020.05.29.20116202; this version posted May 30, 2020. The copyright holder for this preprint (which was not certified by peer review) is the author/funder, who has granted medRxiv a license to display the preprint in perpetuity.

All rights reserved. No reuse allowed without permission.

185 helpful to distinguish PT from other rare primary or secondary sellar tumors whose

186 diagnosis by morphologic and immunohistochemical approaches may be challenging,

187 unavailable and/or inconclusive (e.g. craniopharyngioma variants, lymphoma, metastasis

188 etc) $5,34,45,46$.

189 In conclusion, our results indicate that similar to malignant tumors, PT releases

190 circulating tumor DNA that present specific methylation patterns, recapitulating molecular

191 features detected in PT-tissue (e.g. adenohypophyseal lineage-related). Serum from

192 patients with PT provides tumor-specific methylation signatures that allow the

193 classification of samples into PT subtypes or non-PT groups. Finally, our preliminary

194 results underpin the potential application of methylation profile in the serum-based liquid

195 biopsy as a noninvasive approach to assess clinically relevant epigenetic features useful

196 for clinical purposes in the management of patients (e.g. aggressiveness markers,

197 actionable markers to guide future clinical trials to treat aggressive, resistant or recurrent

198 PT etc). 
medRxiv preprint doi: https://doi.org/10.1101/2020.05.29.20116202; this version posted May 30, 2020. The copyright holder for this preprint (which was not certified by peer review) is the author/funder, who has granted medRxiv a license to display the preprint in perpetuity.

\section{Methods}

200 Patients - We conducted a retrospective analysis of a cohort comprised of archival serum

201 and paired tissue (fresh-frozen) from 13 patients who underwent transsphenoidal surgery

202 for the resection of invasive $(n=5)$ or noninvasive $(n=8)$ macroadenomas of different 203 functional status and histological subtypes ( 9 nonfunctioning: 4 gonadotroph and 5 null 204 cell and 4 functioning: 2 lactotroph, 1 corticotroph and 1 mixed GH/PRL/TSH) (Table 1). 205 Criteria for invasiveness was based on Knosp grades 3-4 ( $n=4)$ or invasion of clivus $(n=1)$ 206 47,48. MRI assessment for size, and invasiveness classification was blindly and 207 independently performed by two physicians from the Henry Ford Health System (HFHS)

208 (TA, KPA). HFHS Pathologists provided a comprehensive pathology report on 209 adenohypophyseal immunostaining, necrosis and quantification of markers of 210 proliferation (Ki-67, mitotic counts, p53). Control serum was obtained from patients 211 without PT (three epileptic patients and one with a nontumor condition). Control pituitary 212 tissue was obtained from non-neoplastic pituitary harvested at autopsy (FFPE). We also 213 generated serum methylome data from patients with glioma $(n=114)$, meningiomas $(n=6)$ 214 and other CNS conditions (brain metastasis, 1 brain colloid cyst, 6 brain radiation 215 necrosis) (Supplemental Table 2) The project was approved by the HFHS Institutional 216 Review Board (IRB\# 10963) and patients consented to have their specimens used for 217 research purposes. Publicly available methylome data from colorectal carcinoma was 218 retrieved (CRC, $\mathrm{n}=2$ pooled samples) ${ }^{49}$.

\section{Serum collection and processing}


medRxiv preprint doi: https://doi.org/10.1101/2020.05.29.20116202; this version posted May 30, 2020. The copyright holder for this preprint (which was not certified by peer review) is the author/funder, who has granted medRxiv a license to display the preprint in perpetuity.

All rights reserved. No reuse allowed without permission.

222 Serum sample was separated within 1 hour from collection by centrifugation at $1,300 \times \mathrm{g}$

223 for 10 minutes at $20^{\circ} \mathrm{C}$; aliquoted into up to five $2 \mathrm{~mL}$ cryovials and stored at $-80^{\circ} \mathrm{C}$ until

224 processing. The methods for the publicly available data is described in their respective

225 manuscripts 49

226

DNA isolation, quantification, and DNA methylation data generation

Tissue and serum DNA were extracted from 2.2-9.3mL aliquots of serum using the

Quick-cfDNA Serum \& Plasma Kit according to the manufacturer's protocol (Zymo

Research - catalog \# D4076). DNA concentration was measured with Qubit (Thermo

230 Fisher Scientific) /or with 4200 TapeStation (Agilent Technologies). The concentration of

231 cfDNA in the serum was calculated by dividing the total amount of cfDNA extracted by

232 the amount of serum used for extraction. We then converted the concentration of cfDNA

233 in the serum $(\mathrm{ng} / \mathrm{mL})$ into haploid genome equivalents $/ \mathrm{mL}$ by multiplying by a factor of

234303 (assuming the mass of a haploid genome $3.3 \mathrm{pg}$ ) ${ }^{50}$.

235 The extracted DNA (30-300 ng) was bisulfite-converted (Zymo EZ DNA

236 methylation Kit; Zymo Research) and profiled using an Illumina Human EPIC array

237 (HM850K), at the USC Epigenome Center, Keck School of Medicine, University of

238 Southern California, Los Angeles, California. The raw DNA methylation data reported in

239 this paper has been deposited to Mendeley Data at

240 https://data.mendeley.com/datasets/cgrz6zztfg.

\section{DNA methylation pre-processing}

$242 \quad$ Methylation array data was processed with the minfi package in $\mathrm{R}$. The raw signal

243 intensities were extracted from the *.IDAT files and corrected for background

244 fluorescence intensities and red-green dye-bias using the function preprocess Noob as 
medRxiv preprint doi: https://doi.org/10.1101/2020.05.29.20116202; this version posted May 30, 2020. The copyright holder for this preprint (which was not certified by peer review) is the author/funder, who has granted medRxiv a license to display the preprint in perpetuity.

All rights reserved. No reuse allowed without permission.

245 described by Triche et al., $2013^{51}$. The beta-values were calculated as $(M /(M+U))$, in 246 which $\mathrm{M}$ and $\mathrm{U}$ refer to the (pre-processed) mean methylated and unmethylated probe

247 signal intensities, respectively. Measurements in which the fluorescent intensity was not

248 statistically significant above background signal (detection $p$ value $>10^{-16}$ ) were removed

249 from the data set. Before the analysis, we filtered out probes that were designed for

250 sequences with known polymorphisms or probes with poor mapping quality (complete list

251 of masked probes provided by Zhou et al. ${ }^{52}$ ) and the $X$ and $Y$ chromosomes.

252 Deconvolution

253 We applied a previously described methodology 50 to deconvolute the relative

254 contribution of cell types to a given sample ${ }^{50}$. We included methylation signatures from

255 cell lines, immune cells (B-cell, CD4T, CD8T, natural killer cells and white blood cells

256 (monocytes, neutrophils) and vascular endothelial cells ${ }^{50}$ (Supplemental Table 2) For

257 lack of information related to methylation signatures from individual cells that comprise

258 the pituitary gland, we generated genome-wide methylation signatures from bulk non-

259 neoplastic pituitaries obtained from cadavers (unpublished data) and followed the steps

260 for defining the signatures as previously described ${ }^{50}$. Briefly, we selected the 100 most

261 specific hypermethylated and hypomethylated CpG probes for each cell/tissue type of

262 interest. Using this signature, we applied a non-negative least squares method to

263 deconvolute our serum and tissue cohort using the standalone program provided by Moss

264 and colleagues ${ }^{50}$. We then normalized the percentages generated by the standalone 265 program for each cell type/PT-tissue from 0 to 100 by serum. 
medRxiv preprint doi: https://doi.org/10.1101/2020.05.29.20116202; this version posted May 30, 2020. The copyright holder for this preprint (which was not certified by peer review) is the author/funder, who has granted medRxiv a license to display the preprint in perpetuity.

All rights reserved. No reuse allowed without permission.

In order to evaluate the DNA methylation profile in the serum from patients with distinct tumor types and non-neoplastic brain diseases, we performed a genome-wide Principal Component Analysis (PCA) across the samples $(\mathrm{N}=147)$ using the function prcomp (version 3.6.0). Consensus clustering was determined by k-means clustering of

271 euclidean distance from the ConsensusClusterPlus (version 1.48.0) package.

\section{Supervised analysis}

We also performed an epigenome-wide differential analysis across the serum from

27410 patients with PT and 105 with non-PT conditions patients (4 non-tumor, 114 glioma, 3

275 meningioma, 1 brain metastasis carcinoma, 1 colloid cyst, and 4 from other CNS necrotic

276 tumors). We used the Wilcoxon rank-sum test to identify differentially methylated probes

277 between two different pairs: PT vs non-PT and functioning vs nonfunctioning PT.

279 methylated when the false discovery rate (FDR) was less than .001 and absolute value 280 of the difference of a pair of probe mean methylation between each group was greater

281 than $20 \%$. To identify DMP in the serum that were tissue-specific, we calculated the 282 differences in DNA methylation between the matching serum and tissue, by patient. We 283 then selected probes with less than 5\% difference between tissue and serum and 284 considered them tissue-specific.

285 To validate their PT-specificity, we overlapped PeLB probes with the DNA 286 methylome of an independent cohort consisting of pituitary-, glioma- and meningioma287 tissue (Figure 1D).

For the comparison between functioning and nonfunctioning, probes were 289 considered differentially methylated when the $\mathrm{p}$-value was less than .01 and absolute 
medRxiv preprint doi: https://doi.org/10.1101/2020.05.29.20116202; this version posted May 30, 2020. The copyright holder for this preprint (which was not certified by peer review) is the author/funder, who has granted medRxiv a license to display the preprint in perpetuity.

All rights reserved. No reuse allowed without permission.

290 value of the difference of probe mean methylation between each group was greater than

$29120 \%$.

\section{Random Forest}

We used a random forest machine-learning $(\mathrm{ML})$ model for binary classification of

294 the specimens with the aim to classify available cfDNA methylation (from serum) derived

295 from patients with PT and non-PT (other neoplastic or non-neoplastic conditions:

296 meningioma, glioma and colorectal carcinoma and nontumor). We first randomly

297 allocated $20 \%$ of all samples for the validation set ( $n=3$ PT; $n=29$ Non-PT) only analyzed

298 for the assessment of the prediction model accuracy. The remainder serum specimens

299 were used for the feature extraction or training of the random forest model. For developing

300 the model we randomly partitioned the remainder samples into a training $(\mathrm{n}=8 \mathrm{PT} ; \mathrm{n}=$

30184 Non-PT) and testing set $(n=2$ PT; $n=21$ Non-PT). We used the function train

302 (package caret version 6.0.82) in CRAN, with 5000 trees, and 10 fold cross validation to 303 generate our model. When testing the model, we used an output of $50 \%$ probability as a

304 cut-off for classification.

305 Based on this result, we adopted the default PeLB score cutoff value of 50 to 306 determine whether a patient had PT. We evaluated the performance of the prediction by 307 applying the ML model on the validation set.

308 Probe annotation

CpG probes were mapped to their CpG genomic location as CpG islands (CGI),

310 shores, shelves, and open sea regions as previously defined ${ }^{52-55}$.

\section{Statistical analysis}


medRxiv preprint doi: https://doi.org/10.1101/2020.05.29.20116202; this version posted May 30, 2020. The copyright holder for this preprint (which was not certified by peer review) is the author/funder, who has granted medRxiv a license to display the preprint in perpetuity.

All rights reserved. No reuse allowed without permission.

312 All processing and statistical analyses were done in $\mathrm{R}$ (3.6.1). Wilcoxon rank-sum test

313 and multiple testing adjustments (e.g. FDR) were used to identify differentially

314 methylated probes (DMP) as stated in the previous sections.

\section{Supplementary information}

\section{Acknowledgements}

317 The authors are grateful to the HFHS patients who consented to the usage of PT for

318 research purposes. We thank Nancy Takacs and Heather Mengel for their

319 administrative support; Kevin Nelson for the collection, handling and maintenance of the

320 tumor bank at the Hermelin Brain Tumor Center; Andrea Transou for tumor pathology

321 processing; Laura A. Hasselbach for DNA extraction; Daniel Weisenberger and team at

322 USC Epigenome Center for assistance with DNA methylation profiling (HFHS support);

323 Susan MacPhee for proofreading the manuscript.

\section{Funding}

325 This work was supported by the Henry Ford Health System, Department of

326 Neurosurgery, and the Hermelin Brain Tumor Center. MSM and MC are supported by

327 the São Paulo Research Foundation (FAPESP), Brazil ( \#16/11039-3; \#17/10357-

328 4,\#14/03989-6); AVC and KPA by Henry Ford Hospital (A30935, A30957; GME

329 202199); LMP, HN, AD, MW, and AM by the National Institutes of Health

330 (R01CA222146), HN, TSS, TMM, LMP, and AD are supported by the Department of

331 Defense (CA170278).

\section{Author contributions}

333 Overall concept and coordination of the study: AVC, JR, HN, KPA; retrieval of publicly

334 available molecular and clinical data: KPA, MW, AVC; Bioinformatic and statistical 
medRxiv preprint doi: https://doi.org/10.1101/2020.05.29.20116202; this version posted May 30, 2020. The copyright holder for this preprint (which was not certified by peer review) is the author/funder, who has granted medRxiv a license to display the preprint in perpetuity.

All rights reserved. No reuse allowed without permission.

335 analyses: MW, TSS, TMM, MSM, HN and input from LMP; HFHF cohort: pathology

336 review AM, DC; molecular data generation: TMM, AD; the manuscript was written by

337 AVC, HN, MW and intellectual contribution from JS, TM, SK, TW. All authors

338 contributed to the revision of the manuscript.

339 Data availability

340 The data is available under the accession code GSEXXXX. All the other data supporting

341 the findings of this study are available within the article and supplemental information

342 and from the corresponding author upon reasonable request.

\section{Competing interests}

344 The authors declare to have no competing interests.

\section{Footnotes}

346 These authors contributed equally as first authors: Michael Wells, Karam P. Asmaro,

347 Thais S. Sabedot, Tathiane M. Malta, and Maritza S. Mosella. These authors

348 contributed equally as senior authors: Houtan Noushmehr, Ana Valeria Castro

349 Contributor information

350 Ana Valeria Castro, Email: acastro1@hfhs.org

351 Houtan Noushmehr, Email:hnoush1@hfhs.org 
medRxiv preprint doi: https://doi.org/10.1101/2020.05.29.20116202; this version posted May 30, 2020. The copyright holder for this preprint (which was not certified by peer review) is the author/funder, who has granted medRxiv a license to display the preprint in perpetuity.

TABLE LEGENDS

354 Table 1-Summary of clinicopathological features of patients included in this study.

\section{FIGURE LEGENDS}

356 Figure 1: Genome-wide DNA methylation profile of pituitary serum cfDNA.

357 Identification of tissue-specific probes that distinguish pituitary serum from non-pituitary 358 serum specimens (ㄹituitary-tumor specific Eppigenetic Liquid-biopsy or PeLB probes).

359 (A) PCA of the mean methylation of pituitary tumors and non-pituitary tumors (glioma, meningioma and colorectal carcinoma) and controls (nontumor conditions). (B) Heatmap depicting the methylation levels of PeLB probes across the entire serum cohort ( $\mathrm{n}=107)$; (C) Heatmap highlights the methylation levels of PeLB probes across pituitary samples and overlapping clinicopathological annotations such as functional and invasion status, transcription factor-related adenohypophyseal cell lineage. (D) The tDistributed Stochastic Neighbor Embedding (t-SNE) plot depicts the overlap of PeLB probes with the methylome of serum specimens from patients harboring pituitary tumors and of the tissue methylome from PT and other CNS tumors (glioma, meningioma). (E) Workflow of sample partitioning of serum cohort for training, testing, and validation used in the random forest analysis to distinguish pituitary tumors from non-pituitary tumors (colorectal carcinoma, glioma, meningiomas). Each test tube represents $10 \%$ of the samples. (F) Boxplot of the PeLB score results from the validation set. The dotted line at $50 \%$ represents the cutoff used for classification into pituitary tumors and non-pituitary samples.

374 Figure 2: Supervised analysis to identify tissue-specific probes that distinguish serum originated from functioning pituitary tumor from those from nonfunctioning PT (Functioning Pituitary-tumor specific Épigenetic Liquid-biopsy-PeLB or FuncPeLB).

378 (A) Heatmap displays the methylation levels of the 70 Func-PeLB differentially methylated 379 probes (DMP) in the serum of nontumor and tumor pituitary specimens. (B) Heatmap 380 displays the 22 Func-PeLB porbes that overlap with the 450K array in nontumor and 381 pituitary tumor tissue (C) PCA of pituitary tumor tissue from an independent cohort using 382 the 22 Func-PeLB probes showing that they segregate samples based on functional 
medRxiv preprint doi: https://doi.org/10.1101/2020.05.29.20116202; this version posted May 30, 2020. The copyright holder for this preprint (which was not certified by peer review) is the author/funder, who has granted medRxiv a license to display the preprint in perpetuity.

All rights reserved. No reuse allowed without permission.

383 status in both tissue and serum. (D) Box plots of serum (left) and tissue (right) mean

384 methylation for each PT (functioning and nonfunctioning) and nontumors samples.

\section{SUPPLEMENTAL INFORMATION}

387 Supplemental Table 1 - (A) Distribution of the number of the most variant methylated

388 probes in the serum and in the pituitary tumor tissue according to their genomic context

389 and CpG location. (B) Distribution of the number of differentially methylated probes

390 (PeLB and Func-PeLB) according to their genomic context and CpG location.

392 Supplemental Figure 1 - (A) Cell-free DNA concentration in the serum derived from 393 patients with nontumor and tumor conditions. (B) Cell-free DNA concentration in the 394 serum of patients with pituitary tumors (PT) according to function and invasion status.

395 (C) Deconvolution of serum in relation to cell composition from control or pituitary tumor 396 patients. (D) Workflow displaying the selection criteria of pituitary tumor- and

397 functioning-specific methylated probes from the supervised analysis between PT and 398 non-PT (right) and Functioning and nonfunctioning PT (left) in the serum. (E) Heatmap 399 displaying the genome-wide methylation profile across PT tissue-specimens.

400

401 
medRxiv preprint doi: https://doi.org/10.1101/2020.05.29.20116202; this version posted May 30, 2020. The copyright holder for this preprint (which was not certified by peer review) is the author/funder, who has granted medRxiv a license to display the preprint in perpetuity.

404 1. Megnis, K. et al. Evaluation of the possibility to detect circulating tumor DNA from pituitary adenoma. Front Endocrinol (Lausanne) 10, 615 (2019).

2. Mouliere, F. et al. High fragmentation characterizes tumour-derived circulating DNA. PLOS ONE 6, e23418 (2011).

3. Jiang, P. \& Lo, Y. M. D. The Long and Short of Circulating Cell-Free DNA and the Ins and Outs of Molecular Diagnostics. Trends Genet. 32, 360-371 (2016).

4. Heitzer, E. \& Speicher, M. R. One size does not fit all: Size-based plasma DNA diagnostics. Sci. Transl. Med. 10, (2018).

5. Shen, S. Y. et al. Sensitive tumour detection and classification using plasma cellfree DNA methylomes. Nature 563, 579-583 (2018).

6. Kim, H., Wang, X. \& Jin, P. Developing DNA methylation-based diagnostic biomarkers. J. Genet. Genomics 45, 87-97 (2018).

416 7. Wang, J. \& Bettegowda, C. Applications of DNA-Based Liquid Biopsy for Central Nervous System Neoplasms. J. Mol. Diagn. 19, 24-34 (2017).

8. Best, M. G. et al. Liquid biopsies in patients with diffuse glioma. Acta Neuropathol. 129, 849-865 (2015).

9. Adamczyk, L. A. et al. Current Understanding of Circulating Tumor Cells - Potential Value in Malignancies of the Central Nervous System. Front. Neurol. 6, 174 (2015).

10. Saenz-Antoñanzas, A. et al. Liquid biopsy in glioblastoma: opportunities, applications and challenges. Cancers (Basel) 11, (2019).

424 11. Bos, M. K. et al. Whole exome sequencing of cell-free DNA - A systematic review and Bayesian individual patient data meta-analysis. Cancer Treat. Rev. 83, 101951 (2020). 
medRxiv preprint doi: https://doi.org/10.1101/2020.05.29.20116202; this version posted May 30, 2020. The copyright holder for this preprint (which was not certified by peer review) is the author/funder, who has granted medRxiv a license to display the preprint in perpetuity.

All rights reserved. No reuse allowed without permission.

427

428

429

430

431

432

433

434

435

436

437

438

439

440

441

442

443

444

445

446

447

448

449

12. Koeppel, F. et al. Whole exome sequencing for determination of tumor mutation load in liquid biopsy from advanced cancer patients. PLOS ONE 12, e0188174 (2017).

13. Neou, M. et al. Pangenomic classification of pituitary neuroendocrine tumors. Cancer Cell (2019). doi:10.1016/j.ccell.2019.11.002

14. Bi, W. L. et al. Landscape of genomic alterations in pituitary adenomas. Clin. Cancer Res. 23, 1841-1851 (2017).

15. Song, Z.-J. et al. The genome-wide mutational landscape of pituitary adenomas. Cell Res. 26, 1255-1259 (2016).

16. Ling, C. et al. A pilot genome-scale profiling of DNA methylation in sporadic pituitary macroadenomas: association with tumor invasion and histopathological subtype. PLOS ONE 9, e96178 (2014).

17. Kober, P. et al. DNA methylation profiling in nonfunctioning pituitary adenomas. Mol. Cell. Endocrinol. 473, 194-204 (2018).

18. Salomon, M. P. et al. The Epigenomic Landscape of Pituitary Adenomas Reveals Specific Alterations and Differentiates Among Acromegaly, Cushing's Disease and Endocrine-Inactive Subtypes. Clin. Cancer Res. 24, 4126-4136 (2018).

19. Duong, C. V. et al. Quantitative, genome-wide analysis of the DNA methylome in sporadic pituitary adenomas. Endocr. Relat. Cancer 19, 805-816 (2012).

20. Capper, D. et al. DNA methylation-based classification of central nervous system tumours. Nature 555, 469-474 (2018).

21. Gu, Y. et al. Differential DNA methylome profiling of nonfunctioning pituitary adenomas suggesting tumour invasion is correlated with cell adhesion. $J$ 
medRxiv preprint doi: https://doi.org/10.1101/2020.05.29.20116202; this version posted May 30, 2020. The copyright holder for this preprint (which was not certified by peer review) is the author/funder, who has granted medRxiv a license to display the preprint in perpetuity.

Neurooncol 129, 23-31 (2016).

22. Zhou, Y., Zhang, X. \& Klibanski, A. Genetic and epigenetic mutations of tumor suppressive genes in sporadic pituitary adenoma. Mol. Cell. Endocrinol. 386, 16-33 (2014).

454 23. Torregrosa-Quesada, M. E. et al. How Valuable Is the RT-qPCR of PituitarySpecific Transcription Factors for Identifying Pituitary Neuroendocrine Tumor

24. Moran, S. et al. Epigenetic profiling to classify cancer of unknown primary: a multicentre, retrospective analysis. Lancet Oncol. 17, 1386-1395 (2016).

25. Hoadley, K. A. et al. Cell-of-Origin Patterns Dominate the Molecular Classification of 10,000 Tumors from 33 Types of Cancer. Cell 173, 291-304.e6 (2018).

26. Ceccarelli, M. et al. Molecular profiling reveals biologically discrete subsets and pathways of progression in diffuse glioma. Cell 164, 550-563 (2016).

27. Sahm, F. et al. DNA methylation-based classification and grading system for meningioma: a multicentre, retrospective analysis. Lancet Oncol. 18, 682-694

28. Ferraresso, S. et al. DNA methylation profiling reveals common signatures of tumorigenesis and defines epigenetic prognostic subtypes of canine Diffuse Large

29. Mosella, M. S. et al. DNA Methylation-based Signatures Classify Sporadic Pituitary Tumors According to Clinicopathological Features. BioRxiv (2020). doi:10.1101/2020.04.25.061903

472 30. Lokk, K. et al. DNA methylome profiling of human tissues identifies global and 
medRxiv preprint doi: https://doi.org/10.1101/2020.05.29.20116202; this version posted May 30, 2020. The copyright holder for this preprint (which was not certified by peer review) is the author/funder, who has granted medRxiv a license to display the preprint in perpetuity. All rights reserved. No reuse allowed without permission.

tissue-specific methylation patterns. Genome Biol. 15, r54 (2014).

474

475

476

477

478

479

480

481

482

483

484

485

486

487

488

489

490

491

492

493

494

495

31. Yang, X., Gao, L. \& Zhang, S. Comparative pan-cancer DNA methylation analysis reveals cancer common and specific patterns. Brief. Bioinformatics 18, 761-773 (2017).

32. Hao, X. et al. DNA methylation markers for diagnosis and prognosis of common cancers. Proc Natl Acad Sci USA 114, 7414-7419 (2017).

33. Widschwendter, M. et al. Methylation patterns in serum DNA for early identification of disseminated breast cancer. Genome Med. 9, 115 (2017).

34. Constâncio, V. et al. Early detection of the major male cancer types in blood-based liquid biopsies using a DNA methylation panel. Clin. Epigenetics 11, 175 (2019).

35. Kang, S. et al. CancerLocator: non-invasive cancer diagnosis and tissue-of-origin prediction using methylation profiles of cell-free DNA. Genome Biol. 18, 53 (2017).

36. Noushmehr, H. et al. Detection of glioma and prognostic subtypes by non-invasive circulating cell-free DNA methylation markers. BioRxiv (2019). doi:10.1101/601245

37. Mete, O. \& Lopes, M. B. Overview of the 2017 WHO classification of pituitary tumors. Endocr. Pathol. 28, 228-243 (2017).

38. Raverot, G. et al. Risk of Recurrence in Pituitary Neuroendocrine Tumors: A Prospective Study Using a Five-Tiered Classification. J. Clin. Endocrinol. Metab. 102, 3368-3374 (2017).

39. Fernández-Balsells, M. M. et al. Natural history of nonfunctioning pituitary adenomas and incidentalomas: a systematic review and metaanalysis. J. Clin. Endocrinol. Metab. 96, 905-912 (2011).

40. Vasiljevic, A., Jouanneau, E., Trouillas, J. \& Raverot, G. Clinicopathological 
prognostic and theranostic markers in pituitary tumors. Minerva Endocrinol. 41, 377-389 (2016).

41. Selman, W. R., Laws, E. R., Scheithauer, B. W. \& Carpenter, S. M. The occurrence of dural invasion in pituitary adenomas. J. Neurosurg. 64, 402-407 (1986).

42. Asioli, S. et al. Validation of a clinicopathological score for the prediction of postsurgical evolution of pituitary adenoma: retrospective analysis on 566 patients from

43. Trouillas, J. et al. A new prognostic clinicopathological classification of pituitary adenomas: a multicentric case-control study of 410 patients with 8 years postoperative follow-up. Acta Neuropathol. 126, 123-135 (2013).

44. Melmed, S. Pituitary-Tumor Endocrinopathies. N. Engl. J. Med. 382, 937-950 (2020).

45. Nunes, S. P. et al. Subtyping lung cancer using DNA methylation in liquid biopsies. J. Clin. Med. 8, (2019).

46. Roy, D. \& Tiirikainen, M. Diagnostic power of DNA methylation classifiers for early detection of cancer. Trends Cancer 6, 78-81 (2020).

47. Micko, A. S. G., Wöhrer, A., Wolfsberger, S. \& Knosp, E. Invasion of the cavernous sinus space in pituitary adenomas: endoscopic verification and its correlation with

48. Knosp, E., Steiner, E., Kitz, K. \& Matula, C. Pituitary adenomas with invasion of the cavernous sinus space: a magnetic resonance imaging classification compared

518 49. Gallardo-Gómez, M. et al. A new approach to epigenome-wide discovery of non- 
invasive methylation biomarkers for colorectal cancer screening in circulating cellfree DNA using pooled samples. Clin. Epigenetics 10, 53 (2018).

521 50. Moss, J. et al. Comprehensive human cell-type methylation atlas reveals origins of 522 circulating cell-free DNA in health and disease. Nat. Commun. 9, 5068 (2018).

523 51. Triche, T. J., Weisenberger, D. J., Van Den Berg, D., Laird, P. W. \& Siegmund, K.

524 D. Low-level processing of Illumina Infinium DNA Methylation BeadArrays. Nucleic Acids Res. 41, e90 (2013).

526 52. Zhou, W., Laird, P. W. \& Shen, H. Comprehensive characterization, annotation and 527 innovative use of Infinium DNA methylation BeadChip probes. Nucleic Acids Res. 45, e22 (2017).

53. Gardiner-Garden, M. \& Frommer, M. CpG islands in vertebrate genomes. J. Mol. Biol. 196, 261-282 (1987).

531 54. Sandoval, J. et al. Validation of a DNA methylation microarray for 450,000 CpG sites in the human genome. Epigenetics 6, 692-702 (2011).

533 55. Takai, D. \& Jones, P. A. The CpG island searcher: a new WWW resource. In Silico Biol (Gedrukt) 3, 235-240 (2003). 
Pituitary Serum - Functioning PeLB (Func-PeLB)

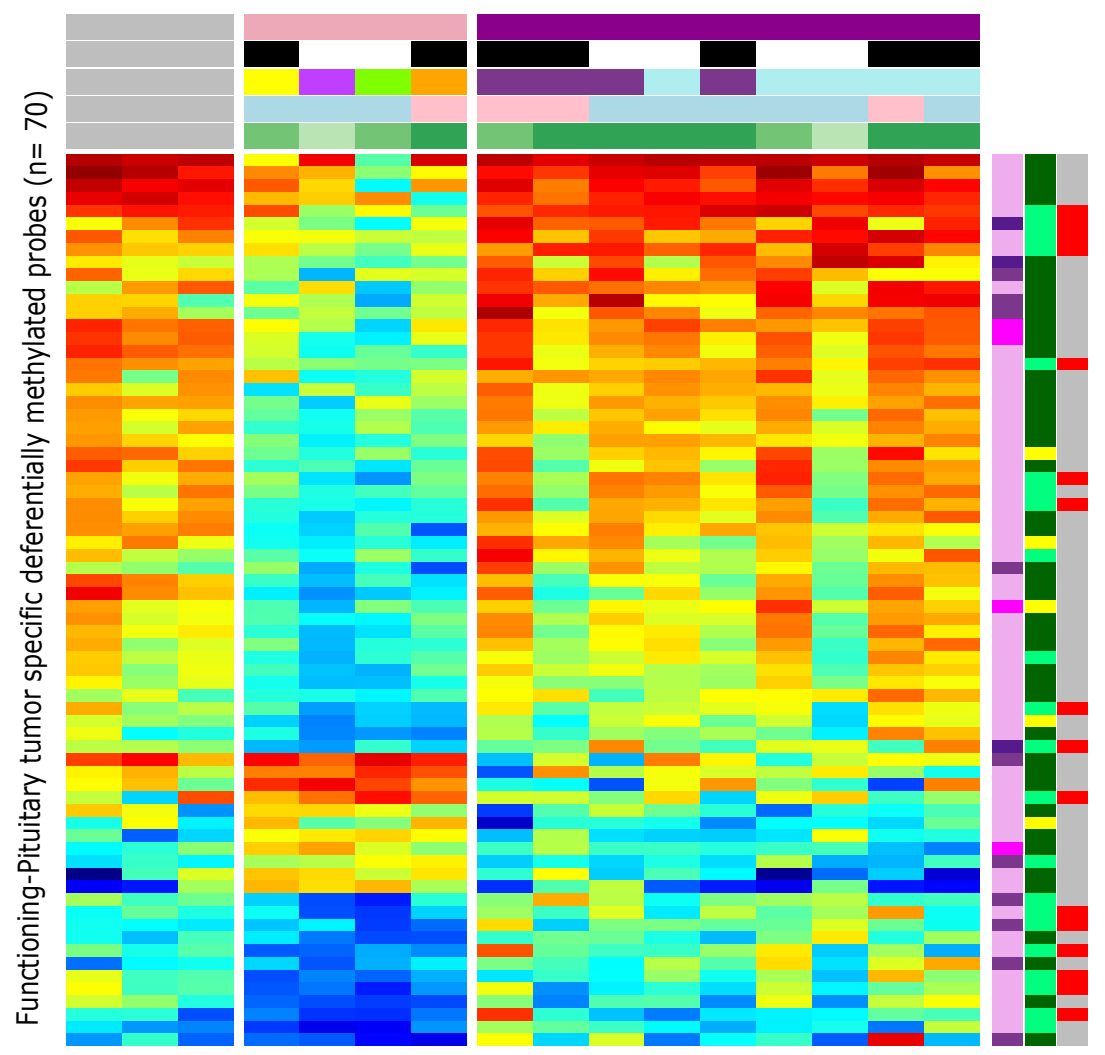

Functioning-PeLB probes $(450 K)(\mathrm{n}=22)$

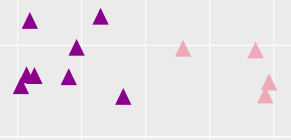

D

Functional Status

- Functioning PT
Specimen

Serum

- Tissue
Pituitary Tissue - Functioning PeLB (Func-PeLB)
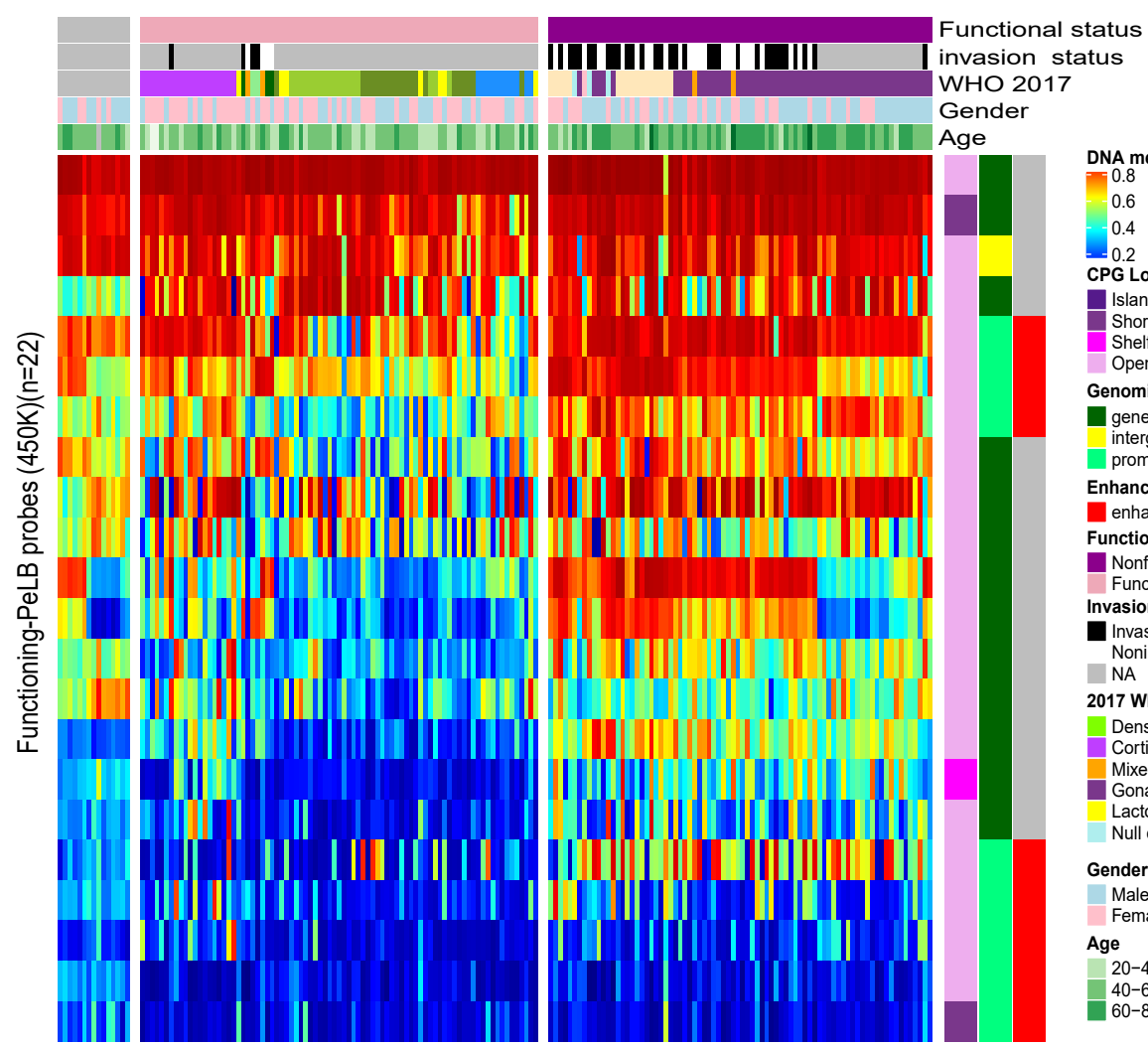

DNA meth

0.8
0.6

0.4
-0.2

CPG Location

Island
Oshore
Shelf

Open Sea

Genomic Location

gene.body
intergenic

intergenic
promoter

Enhancer

Enhancer

Functional Status

Nonfunctioning

Functioning

1 Invasive

NAninvasive

2017 WHO Classification

Densely.mammotroph

Corticotroph

Gonadotroph

Lactotroph
Null cell

Gender

Male
Female

Age

$20-40$
$40-60$
$60-80$

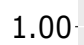

Serum
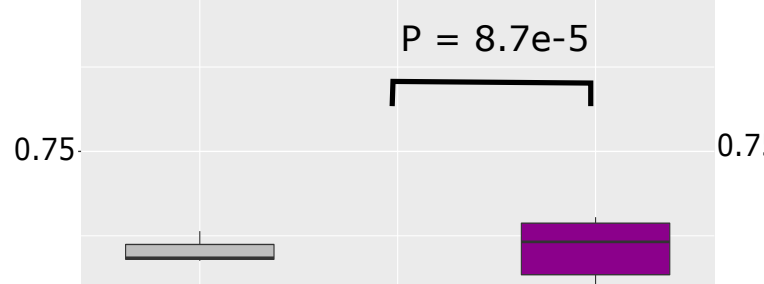

0.25

0.00

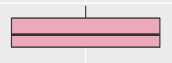

0.75

Tissue

$$
\mathrm{P}<2.2 \mathrm{e}-16
$$
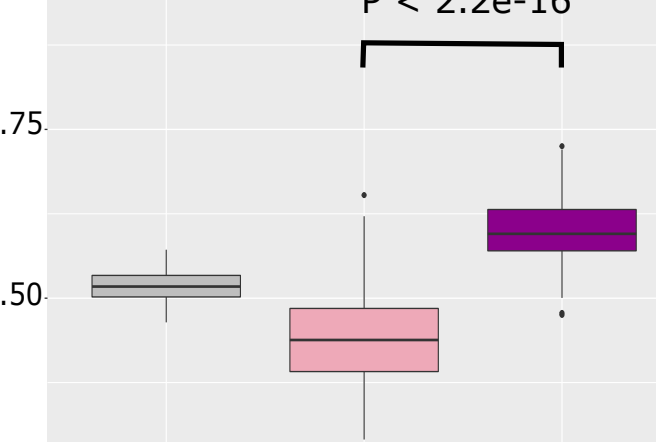

0.25

0.00

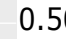

自 Non Tumor

帛 Functioning PT
Nonfunctioning PT

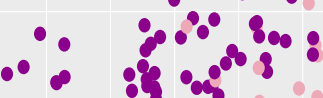

-

$\begin{array}{lllll}-1.0 & -0.5 & 0.0 & 0.5 & 1.0\end{array}$

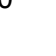


medRxiv preprint doi: https://doi.org/10.1101/2020.05.29.20116202; this version posted May 30, 2020. The copyright holder for this preprint (which was not certified by peer review) is the author/funder, who has granted medRxiv a license to display the preprint in perpetuity.

All rights reserved. No reuse allowed without permission.

Table 1- Summary of the clinicopathological features from patients harboring pituitary tumors and nontumor conditions (serum)

\begin{tabular}{|c|c|c|c|}
\hline Feature & Nontumor $(n=4)$ & NFPT $(n=9)$ & FPT $(n=4)$ \\
\hline \multicolumn{4}{|l|}{ Gender } \\
\hline Female & 1 & 3 & 1 \\
\hline Male & 2 & 6 & 3 \\
\hline Unknown & 1 & 0 & 0 \\
\hline \multicolumn{4}{|l|}{ Age at surgery (years) } \\
\hline Median (Lower and upper quartile) & $31(22-60)$ & $65(57-68)$ & $52(46-57)$ \\
\hline \multicolumn{4}{|l|}{2017 WHO/Hormone staining } \\
\hline Gonadotroph/LH and/or FSH & - & 4 & - \\
\hline Null Cell & - & 5 & - \\
\hline Corticotroph/ACTH & - & - & 1 \\
\hline Mixed/GH/PRL/TSH & - & - & 1 \\
\hline Lactotroph/PRL & - & - & 1 \\
\hline Densely lactotroph/PRL & - & - & 1 \\
\hline \multicolumn{4}{|l|}{ Invasion status } \\
\hline Invasive & - & 5 & 2 \\
\hline Noninvasive & - & 4 & 2 \\
\hline \multicolumn{4}{|l|}{ Size } \\
\hline Micro_<1cm & - & 0 & 1 \\
\hline Macro_ $\geq 1-4 \mathrm{~cm}$ & - & 7 & 2 \\
\hline Giant $\_4 \mathrm{~cm}$ & - & 2 & 1 \\
\hline
\end{tabular}

Legend - FPT: Functioning pituitary tumor. ACTH: Adrenocorticotropic hormone; GH: Growth hormone; PRL: prolactin; LH: luteinizing hormone; FSH: follicle stimulating hormone 